\title{
Giant cell tumor of tendon sheath: a multicentric presentation
}

\author{
Pallavi Bhuyan, Pranati Mohanty, Subrat Burma, Shivangi J . Harankhedkar, Mitali M. Rath \\ Department of Pathology, S. C. B. Medical College, Cuttack, Odisha, India \\ Correspondence: Pallavi Bhuyan. Address: Department of Pathology, S. C. B. Medical College, Cuttack. 753007, Odisha, \\ India. E-mail: drpallavibhuyan@gmail.com
}

Received: March 16, 2014

DOI : $10.5430 /$ crcp.v1n2p138
Online Published: June 23, 2014

URL: http://dx.doi.org/10.5430/crcp.v1n2p138

\section{Abstract}

Giant cell tumor of the tendon sheath (GCTTS) is a relatively common soft tissue neoplasm arising from the tendon sheaths of upper and lower extremities. However, the incidence of GCTTS at multiple sites is not yet reported in literature which is extremely rare. Here we are reporting a case of a 21 year female presenting with slow growing, firm swellings on bilateral elbow and tendoachilis region. Fine needle aspiration was done from all the sites which revealed the features of GCTTS. This case highlights the unusual multicentric presentation of GCTTS.

\section{Key words}

Giant cell tumor of tendon sheath, Multicentric, Fine needle aspiration cytology

\section{Introduction}

Giant cell tumor of the tendon sheath (GCTTS) most commonly occurs in the flexor aspect of hand and wrist, followed by ankle and foot region ${ }^{[1]}$. Most cases occur as solitary lesions. Only one case of multiple separate GCTTS on thumb has been reported by Park ${ }^{[2]}$. However, there has been no report on simultaneous involvement of this lesion at multiple sites as observed in our case. This is the first case to be reported.

\section{Case report}

A 21 year old female presented with slow growing soft tissue swellings on bilateral elbow and tendoachillis region (see Figure 1). There was no history of trauma. Clinically the patient was active and healthy. The swellings were firm and mild tender in nature. Radiograph revealed no bony involvement. Fine needle aspiration cytology (FNAC) was done from all the swellings. Cytosmear from all the swellings revealed similar picture. Cytosmear was cellular showing a polymorphic population of mononuclear cells, multinucleated osteoclastic type of giant cells and foamy macrophages along with few spindle cells (see Figure 2). A diagnosis of multicentric GCTTS was made. Pigmented villonodular synovitis is a differential diagnosis, but it is distinguished from GCTTS that the former usually arises from the synovial membrane of a joint. Surgical excision followed by histopathological diagnosis confirmed the diagnosis. 
Figure 1. Photograph showing multiple swellings at both elbow and tendoachilis region

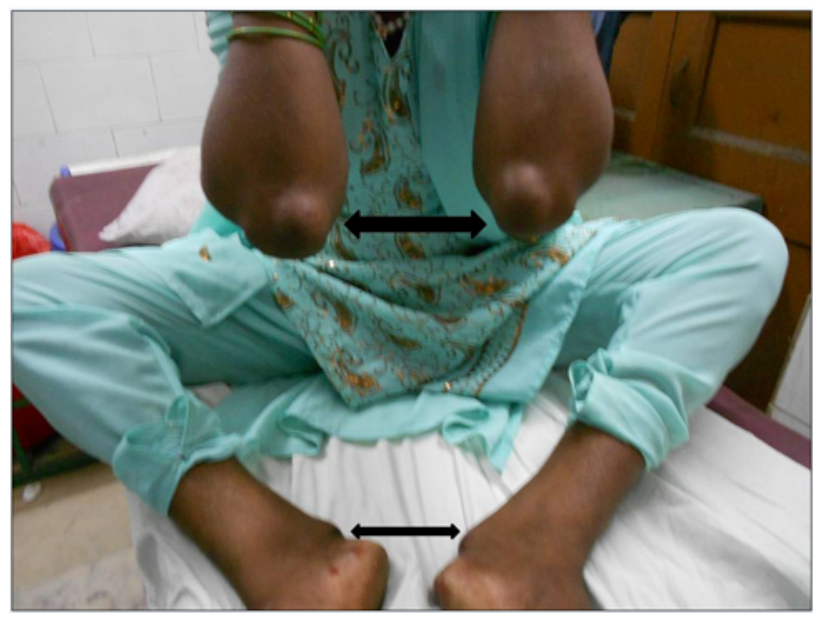

Figure 2. Cytosmear showing multinucleated giant cells and mononuclear stromal cells. (Leishman Stain, 400×)

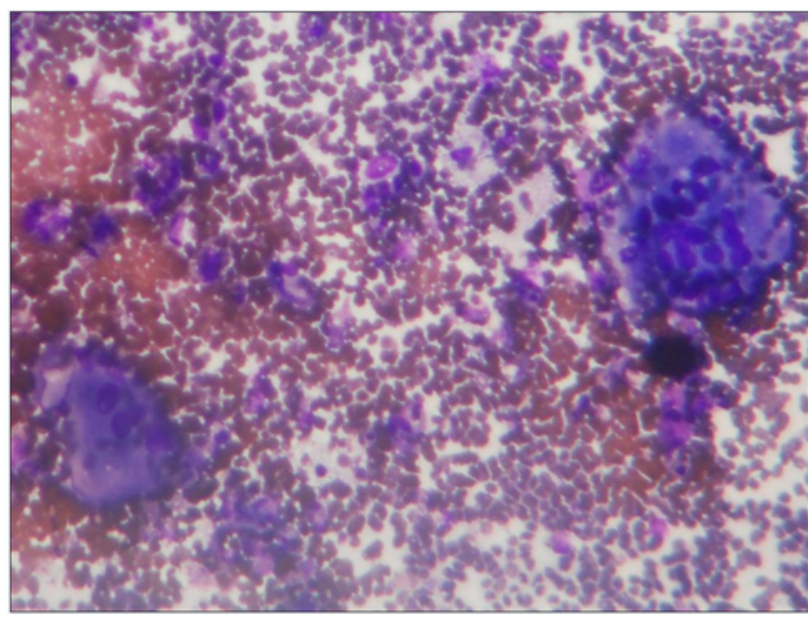

\section{Discussion}

GCTTS is a benign soft tissue tumor that commonly arises from the complex of the tendon sheath and periarticular soft tissue of small joints. Most cases of GCTTS are distributed in hand (between wrist and finger tips) and less commonly in foot (between ankle and toe tips). Other rare sites of involvement of include ankle, knee and hip. Ushijima et al. reported $87.9 \%$ of cases in the digits (fingers and toes) and $12 \%$ in the large joints (knee, elbow, ankle and hip) ${ }^{[3]}$. In a study of 118 cases $77 \%$ of GCTTS were found in the hand while only $3 \%$ in the foot ${ }^{[4]}$. Simultaneous occurrence of GCTTS at multiple sites is almost not reported in the literatures. Park reported multiple separated GCTTS on thumb of a 33 year old male. Zhang et al. reported a single case involving both foot and ankle (on left lateral malleolus and second metatarsal) in a series of 20 cases ${ }^{[5]}$. Ours is the first case to show multicentric presentation of GCTTS.

The exact etiology of GCTTS is unknown. Chassaignac first described these benign soft tissue tumors in 1852 and overstating their biologic potential as cancers of the tendon sheath ${ }^{[6]}$. Pathogenetic theories include inflammatory, neoplastic, traumatic, toxic, allergic and genetic (nm23 gene) factors. The current scenario as proposed by Jaffe et al. is that of a reactive or regenerative hyperplasia associated with an inflammatory process ${ }^{[7]}$. Genetic basis of this tumor was analyzed in few studies. Aneuploid cells have been noted by DNA flow cytometry in a significant number of cases ${ }^{[8]}$. Grover et al. in a study of 52 cases of GCTTS investigated expression of nm23 gene by immunohistochemistry ${ }^{[9]}$. Absence of this gene is associated with a statistically significant risk of local recurrence. Clonal abnormalities like translocation involving chromosomes 1,2 and 16 have also been noted in different studies ${ }^{[10]}$. However, no studies have done regarding the genetic basis multicentric origin of GCT. 
Surgical excision is the curative treatment. However, local recurrence is $9 \%-44 \%$ which is mostly due to incomplete excision of the lesions, especially the satellite nodules. Other factors responsible for local recurrence are proximity to distal interphalangeal joints, presence of degenerative joint disease, high mitotic activity and type-2 lesion described by Al-Qattan ${ }^{[11]}$.

To the best knowledge of the authors, there has been no report of GCTTS occurring simultaneously at both elbow and ankle joints, i.e. multicentric presentation. This case highlights that GCTTS, though commonly present as solitary mass, can also present at multiple sites. FNAC is a quick, simple, inexpensive and valuable tool for early diagnosis and timely management. Many authors emphasized on FNAC as a primary diagnostic aid in soft tissue tumors ${ }^{[12]}$. Multicentric presentation of GCTTs can be diagnosed preoperatively by FNAC that helps in preoperative planning to prevent recurrence.

\section{References}

[1] Arifaizad Abdullah, Shalimar Abdullah, Nor Hazla Mohd Haflah, et al. Giant Cell Tumor of the Tendon Sheath in the Knee of an 11-year-old Girl. J Chin Med Assoc. 2010; 73(1): 47-51. http://dx.doi.org/10.1016/S1726-4901(10)70022-8

[2] Jong Woong Park. Multiple separated giant cell tumors of the tendon sheath in a thumb. Journal of the American Academy of Dermatology. March. 2006; 54(3): 540-542.

[3] Ushijima M, Hashimoto H, Tsuneyoshi M. Giant cell tumor of the tendon sheath (nodular tenosynovitis): a study of 207 cases to compare the large joint group with the common digit group. Cancer. 1986; 57: 875-84. http://dx.doi.org/10.1002/1097-0142(19860215)57:4<875::AID-CNCR2820570432>3.0.CO;2-Y

[4] Jones FE, Soule EH, Coventry MB. Fibrous xanthoma of synovium (giant cell tumor of tendon sheath, pigmented nodular synovitis): a study of one hundred and eighteen cases. J Bone Joint Surg (Am). 1969; 51: 76. PMid: 4303016.

[5] Zhang Y, Huang J, et al. Giant cell tumor of the Tendon sheath in the Foot and Ankle: Case series and Review of Literature. The J of Foot and Ankle Surg. 2013; 52(1): 24-27. PMid: 23085383. http://dx.doi.org/10.1053/j.jfas.2012.09.008

[6] Chassaignac. CME. Cancer de la gaine des tendons. Gaz Hosp Civ Milit. 1852; 47: 185.

[7] Jaffe HL, Lichtenstein HL, Elsutro CJ. Pigmented villonodular synovitis, bursitis, and tenosynovitis. Arch Pathol. 1941; 31: 731-65.

[8] Abdul Karim FW, el-Naggar AK, Joyce MJ, Makley JT, Carter JR. Diffused and localised Tenosynovial giant cell tumor and Pigmented villonodular synovitis: A clinicopathologic and Flow cytometric DNA analysis. Hum Pathol. 1992; 23: 729-35. http://dx.doi.org/10.1016/0046-8177(92)90340-9

[9] Grover R, Grobbelaar AO, Richman PT, Smith PJ. Measurement of invasive potential provides an accurate prognostic marker for giant cell tumor of tendon sheath. J Hand Surg. 1998; 23-B: 728-31. http://dx.doi.org/10.1016/S0266-7681(98)80084-3

[10] Gibbons CLMH, Khwaja HA, et al. Giant cell tumor of the tendon sheath in the foot and ankle. The J of Bone and Joint Surgery (Br). 2002; 84-B: 1000-3. http://dx.doi.org/10.1302/0301-620X.84B7.13115

[11] Suresh SS, Zaki H. Giant cell tumor of tendon sheath: Case series and Review of Literature. J Hand Microsurg. Jul-Dec 2010; 2(2): 67-71. PMid: 22282671. http://dx.doi.org/10.1007/s12593-010-0020-9

[12] Ng VY, Thomas K, Crist M, et al. Fine needle aspiration for clinical triage of extremity soft tissue masses. Clin Orthop Rel Res. 2010; 468: 1120-1128. PMid: 19763717. http://dx.doi.org/10.1007/s11999-009-1100-7 